\title{
Penyiapan calon guru untuk anak berkebutuhan khusus di Indonesia: Kondisi saat ini dan Tantangan
}

\author{
Pujaningsih* \\ Educational Leadership Department, University of Northern Iowa \\ * Corresponding Author. E-mail: pujanin@uni.edu
}

\begin{abstract}
Abstrak: Perkembangan layanan pendidikan khusus menuntut penyiapan kompentensi calon guru yang sesuai dengan tantangan saat ini. Penelitian ini mereviu kurikulum prodi pendidikan khusus jenjang S-1 $(n=7)$ dari total 18 prodi pendidikan khusus di Indonesia. Analisis kurikulum dilakukan dengan dua fokus, yaitu: matakuliah dengan fokus jenis kebutuhan khusus dan matakuliah pendukung kompetensi utama guru khusus (contoh: asesmen, intervensi akademik, intervensi perilaku, layanan transisi, dan layanan kompensatoris). Prosentase matakuliah penunjang kompentensi utama guru pendidikan khusus masih sangat terbatas (rerata = 47\%). Hampir ke-tujuh prodi dalam penelitian ini terfokus pada jenis kekhususan yang ditawarkan dalam matakuliah wajib maupun pilihan berdasarkan kebutuhan khusus. Selain itu, matakuliah untuk menunjang kemampuan guru untuk menerapkan intervensi perilaku maupun layanan transisi tidak selalu dijumpai di setiap prodi pendidikan khusus. Pergeseran fokus kearah kebutuhan khusus disarankan untuk membekali calon guru pendidikan khusus.
\end{abstract}

Kata kunci: penyiapan calon guru, guru pendidikan khusus.

\section{Preparation of teacher candidates for children with special needs in Indonesia: Current conditions and challenges}

\begin{abstract}
The development of special education services requires the alignment of teacher preparation program with current challenges. This study analyzed curriculum of special education programs for undergraduate $(n=7)$ from a total of 18 special education study programs in Indonesia. Curriculum analysis was carried out with two focuses, namely: subjects with a focus on the types of disabilities and subjects that support the primary competencies of special education teachers in providing special education services (examples: assessment, academic intervention, behavioral interventions, transition services, and compensatory services). The percentage of subjects that support the main competency for special education teachers candidates is found minimal (mean = 47\%). Nearly all seven study programs in this study have subjects that focus on the type of disabilities and offer them as both compulsory and elective subjects. Besides, courses to support the ability of teachers to implement behavioral interventions and transitional services are missing in some of special education departments. Shifting focus of special education teacher preparation programs towards the needs of students with special needs is recommended to support more special teacher candidates with high competencies.
\end{abstract}

Keywords: teacher preparation program, special education teacher

\section{PENDAHULUAN}

Layanan pendidikan untuk anak berkebutuhan khusus (ABK) saat ini mengikuti trend pendidikan global dan terjadi di berbagai negara maju maupun berkembang. Pendidikan inklusi menjadi tonggak pergeseran sudut pandang mengenai difabilitas yang awalnya lebih fokus pada layanan yang terfokus pada kondisi disabilitas lalu berangsur mengarah ke penyesuaian lingkungan dengan kebutuhan anak. Berbagai perubahan mendasar dari tempat layanan pendidikan mulai bergeser dari sekolah khusus ke sekolah umum bersama-sama teman sebaya membawa konsekuensi pergeseran penyiapan calon guru khusus yang efektif. Oleh karena itu, bagaimana kompetensi guru khusus yang diperlukan untuk anak berkebutuhan khusus di sekolah inklusi maupun sekolah khusus perlu mempertimbangkan kebutuhan anak dan kebutuhan lapangan sebagai dampak langsung dari kebijakan di level nasional dan local. 
Kompetensi guru untuk anak berkebutuhan khusus dituntut untuk menyesuaikan perkembangan pemberian layanan kebutuhan khusus, kebijakan pendidikan, dan penelitian di area pendidikan khusus (Sindelar, Brownell, \& Billingsley, 2010). Perkembangan layanan pendidikan khusus di Indonesia sudah mengalami banyak kemajuan bila dilihat dari sejak awal pendidikan untuk anak berkebutuhan khusus dimulai pada masa penjajahan Belanda (Rahardja, 2016) sampai saat ini. Saat ini pendidikan inklusi banyak ditemui di berbagai sekolah di seluruh Indonesia sejak mulai diterapkan melalui pilot project di beberapa sekolah di tahun 2001 (Hadis, 2005) dengan dukungan berbagai kebijakan pemerintah di tingkat pusat maupun daerah.

Kebijakan pemerintah dalam penerapan pendidikan inklusi terus mendorong perluasan akses pendidikan bagi anak berkebutuhan khusus dari tahun ke tahun. Permendiknas no 70 tahun 2009 tentang pendidikan inklusi secara khusus mengatur tentang layanan pendidikan untuk anak berkebutuhan khusus sesuai dengan kebutuhan dan kemampuan anak. Secara khusus, dalam peraturan ini diwajibkan penunjukan satu sekolah inklusi di setiap jenjang mulai dari sekolah dasar, sekolah menengah pertama, dan sekolah menengah atas di setiap kecamatan. Pemberlakukan kebijakan ini meningkatkan jumlah sekolah inklusif secara drastis, dari 254 sekolah inklusif di tahun 2008 meningkat menjadi 2.430 sekolah inklusi di tahun 2014 (Koran Sindo, 2016).

Peningkatan jumlah anak berkebutuhan khusus di sekolah umum membutuhkan layanan khusus yang disediakan oleh sekolah. Hal ini masih banyak ditemukan kendala terutama dari sisi keberadaan guru khusus yang masih jarang dijumpai di sekolah inklusi (Tarnoto, 2016), kompetensi guru kelas dan atau bidang study yang belum memadai (Yusuf, 2012), dan penerimaan guru serta teman sebaya yang perlu ditingkatkan (Poernomo, 2016). Penelitian yang dilakukan oleh Sunardi beserta rekan (2011) di tahun 2008 memberikan gambaran bahwa layanan identifikasi, asesmen, dan modifikasi kurikulum bagi anak berkebutuhan khusus masih perlu dukungan berkelanjutan di 186 sekolah inklusi di berbagai propinsi di Indonesia meskipun mereka sudah menerima pelatihan. Terkait dengan ini, persoalan mengenai keterbatasan sikap penerimaan, pengetahuan, dan kemampuan yang mendukung penerapan pendidikan inklusi masih banyak ditemukan (Sari Rudiyati, Pujaningsih, \& Mumpuniarti, 2017; Sunardi et al., 2011), meskipun sikap positif terhadap pendidikan inklusif juga ditemukan (Kurniawati, Minnaert, Mangunsong, \& Ahmed, 2012) namun penggunaan kuesioner untuk melaporkan sikap dalam penelitian ini memerlukan konfirmasi dari penelitian lainnya dengan metode yang berbeda, misal interviu dan observasi. Perubahan layanan pendidikan khusus yang tidak terbatas pada system segregasi ini memerlukan penyesuaian dalam mempersiapkan guru khusus guna mendukung kualitas layanan untuk anak-anak berkebutuhan khusus di sekolah umum maupun sekolah luar biasa (SLB).

Penelitian terdahulu dengan fokus kompetensi guru pendidikan inklusif sudah dilakukan oleh Rudiyati (2012) dan penggunaan evaluasi kinerja guru sekolah inklusif oleh Sunardi dan rekan (2011). Akan tetapi, kompetensi maupun kinerja guru dalam penelitian tersebut tidak dispesifikan untuk guru khusus. Oleh karena itu, penelitian ini ingin mengeksplorasi lebih dalam mengenai penyiapan calon guru khusus di berbagai perguruan tinggi di Indonesia yang berlangsung saat ini dan tantangan pemenuhan kompetensi calon guru khusus di masa mendatang di lihat dari tuntutan kebijakan pemerintah di bidang pendidikan dan perkembangan layanan pendidikan khusus (Sindelar et al., 2010). Kedua hal ini diperuntukkan untuk dmemetakan kebutuhan penyesuaian penyiapan calon guru khusus dan juga mengundang lebih banyak lagi penelitian-penelitian dengan fokus pada penyiapan calon guru khusus dan pembinaan guru khusus

\section{METODE}

Pengambilan sampel universitas. Perguruan tinggi penyelenggara pendidikan calon guru untuk anak berkebutuhan khusus dapat dilihat dalam Tabel 1. Data ini diperoleh dari pangkalan data pendidikan tinggi kemenristek dikti yang diakses pada bulan Maret 2019 dengan dua kata kunci "pendidikan khusus" seperti tertuang dalam nomenklatur dikti dan "pendidikan luar biasa". Ditemukan prodi penyelenggara pendidikan khusus jenjang S1 $(N=18)$, S2 $(N=5)$, dan S3 $(N=1)$ tersebar di pulau Jawa, Sumatra, Kalimantan, dan Sulawesi (lihat Tabel 1). 


\section{JPK (J urnal Pendidikan Khusus), 15 (1), 2019 - 26}

Pujaningsih

Tabel 1: Daftar perguruan tinggi penyelenggara pendidikan khusus tahun 2019

\begin{tabular}{cccccccc}
\hline \multirow{2}{*}{ level } & \multirow{2}{*}{ Jml } & \multicolumn{4}{c}{ Lokasi } & \multicolumn{3}{c}{ Status } \\
\cline { 3 - 7 } & & Jw & Smt & K & L & PTN & PTS \\
\hline S1 & 18 & 13 & 2 & 1 & 2 & 12 & 6 \\
S2 & 5 & 5 & - & - & - & 5 & - \\
S3 & 1 & 1 & - & - & & 1 & -
\end{tabular}

Keterangan: Jw=Jawa, Smt= Sumatra, K=Kalimantan, L=lainnya.

Dalam Tabel 1, sebagian besar perguruan tinggi penyelenggara prodi pendidikan khusus berada di pulau Jawa dari jenjang S1, S2, dan S3 dengan akreditasi beragam dari A sampai C. Penelitian ini terfokus pada jenjang S1 sebagai persyaratan menjadi guru khusus. Seleksi pengambilan sampel kurikulum pendidikan khusus dilakukan dengan memperhatikan akreditasi prodi minimal B, akses kurikulum secara on-line melalui pencarian web, dan sebaran lokasi. Berdasarkan kriteria tersebut maka diperoleh 7 kurikulum penyelenggara pendidikan khusus yang tersebar di Jawa $(n=4)$, Sumatra $(n=1)$, Kalimantan $(n=1)$, dan Sulawesi $(n=1)$, dengan akreditas beragam yang terdiri dari akreditasi A $(n=4)$ dan akreditasi B $(n=2)$. Salah satu prodi pendidikan khusus tertua di Indonesia tetap diikutsertakan meskipun belum tercantum akreditasi berdasar BAN PT dengan asumsi bahwa proses akreditasi sedang berlangsung.

\section{Analisis Kurikulum Pendidikan Khusus}

Informasi mengenai matakuliah yang perlu ditempuh pada jenjang S-1 dikumpulkan berdasarkan kurikulum prodi Pendidikan Khusus. Matakuliah wajib dan matakuliah pilihan dianalisis lebih lanjut. Nama matakuliah dianalisis beserta deskripsi (apabila tersedia) untuk melihat jumlah kredit SKS untuk area-area berikut ini: a) mata kuliah penunjang area kekhususan (area kekhususan yang menjadi fokus dalam kurikulum) dan b) matakuliah penunjang kompetensi guru khusus yang mencakup 1) identifikasi, asesmen dan monitor kemajuan belajar, 2) layanan akademik, 3) penanganan perilaku dan sosial, 4) layanan transisi, 5) layanan kompensatoris, dan 6) kemampuan bekerja dalam tim. Kriteria dari masing-masing perkuliahan dijelaskan sebagai berikut.

Matakuliah penunjang kekhususan. Nama atau deskripsi matakuliah menyebutkan salah satu kebutuhan khusus, misal: anak dengan gangguan intelektual, anak dengan Autism, anak dengan gangguan pendengaran masuk dalam kategori ini disertai keterangan sebagai matakuliah wajib atau pilihan. Nama matakuliah pendidikan anak tunanegra/gangguan penglihatan di masukkan dalam koding beserta besaran SKS yang tercantum. Contoh matakuliah dengan nama pendidikan inklusi dan mencakup berbagai jabaran anak dengan kebutuhan khusus dikelompokkan dalam kategori ini karena membahas berbagai karakteristik anak dengan kebutuhan khusus. Sementara matakuliah umum seperti pendidikan agama, statistik dan matakuliah sejenis lainnya tidak dimasukkan dalam kategori ini karena tidak secara khusus membahas tentang pendidikan anak berkebutuhan khusus. Pengecualian juga dilakukan pada mata kuliah medis pendukung seperti neurology, anatomi fisiologi dengan alasan yang sama. Matakuliah berbasis matapelajaran seperti Bahasa, IPA, IPS, dan Matematika juga tidak dimasukkan dalam kategori ketika terfokus pada penguasaan materi dan bukan pada bagaimana pengajaran materi tersebut untuk anak berkebutuhan khusus.

Kompetensi guru khusus. Nama atau deskripsi matakuliah harus mencakup salah satu dari berbagai kompetensi kekhususan untuk mendidik anak berkebutuhan khusus yang mencakup:

1) Identifikasi, asesmen dan monitor kemajuan belajar. Matakuliah dan atau deskripsi matakuliah yang mencantumkan istilah asesmen, identifikasi, pengukuran (fisiologis maupun psikologis) dan monitoring dalam kurikulum pendidikan guru diklasifikasikan dan dihitung jumlah total SKS untuk setiap kurikulum yang terkumpul. Meskipun ketrampilan asesmen diyakini juga akan dilakukan berulang dalam matakuliah praktik pengajaran, namun dalam penelitian ini hanya mencantumkan berdasarkan nama dan deskripsi matakuliah.

2) Layanan akademik. Matakuliah maupun deskripsi matakuliah yang mencantumkan istilah ortodidaktik yang terfokus pada pengajaran, pengembangan bahan ajar, evaluasi pembelajaran untuk anak berkebutuhan khusus, maupun pembelajaran bidang studi untuk anak berkebutuhan khusus tercakup dalam kategori ini. Nama matakuliah pembelajaran Bahasa Indonesia tanpa 
terfokus pada anak berkebutuhan khusus tidak termasuk ke dalam kategori intervensi akademik karena terfokus pada materi ajar.

3) Penanganan perilaku dan sosial. Matakuliah maupun deskripsi matakuliah yang mencantumkan istilah analisis pengubahan perilaku, modifikasi perilaku, dan pengelolaan kelas masuk dalam kategori ini. Pengelolaan kelas dimasukkan dalam kategori ini terutama untuk kelas inklusi maupun kelas khusus, pengelolaan perilaku terintregrasi dalam pengelolaan kelas secara umum yang melibatkan anak-anak dalam satu kelas.

4) Layanan transisi. Matakuliah maupun deskripsi matakuliah yang mencantumkan istilah transisi ke dunia kerja, transisi ke jenjang sekolah berikutnya, maupun pembinaan karir. Dengan pertimbangan matakuliah bimbingan konseling ABK membahas persiapan anak berkebutuhan khusus menuju dunia karir, maka matakuliah ini dimasukkan dalam kategori ini.

5) Layanan kompensatoris. Matakuliah maupun deskripsi matakuliah yang mencantumkan berbagai istilah penunjang ketrampilan mengajar kompensatoris seperti: braille, bina diri dan gerak, komunikasi alternatif termasuk dalam kategori ini.

6) Kemampuan bekerja dalam tim. Matakuliah maupun deskripsi matakuliah yang mencantumkan istilah kolaborasi, etika profesi, maupun teamwork dimasukkan dalam kategori ini.

\section{HASIL DAN PEMBAHASAN}

Terdapat dua analisis kurikulum yang dilakukan dalam penelitian ini, yaitu: analisis kurikulum berdasarkan jenis kekhususan dan analisis kurikulum berdasarkan kompetensi utama guru khusus.

Jenis Kekhususan dalam Kurikulum S-1 Pendidikan Khusus

Minimum SKS yang perlu ditempuh oleh mahasiswa calon guru khusus seperti tercantum pad Tabel.2 mempunyai rerata-rata $147.57(S D=4.65)$. Dari total SKS tersebut, rerata 100.14 SKS $(S D=$ 14.54) difokuskan pada matakuliah kekhususan prodi dengan minimal 76 SKS dan maksimum 124 SKS.

Ada tiga dari tujuh LPTK penyelenggara prodi pendidikan khusus dalam penelitian ini menawarkan kekhususan dengan rentang SKS mulai dari 8 SKS sampai 16 SKS. Sementara itu keempat LPTK lainnya hanya memberikan matakuliah dengan focus kekhususan sebagai matakuliah wajib dengan kisaran SKS 8 sampai dengan 27 SKS. Total jumlah matakuliah dengan fokus jenis kekhususan di setiap LPTK mempunyai rerata SKS berjumlah 22.86 dengan minimum 18 dan maksimum 29. Salah satu LPTK menyelenggarakan 8 sks matakuliah wajib berdasarkan kekhususan, menawarkan 16 SKS matakuliah untuk setiap jenis kekhususan yang ingin didalami oleh calon guru khusus. Sementara itu, LPTK tanpa pilihan jenis spesialisasi bidang kekhususan, memberikan matakuliah beragam jenis kekhususan mulai dari 18 SKS sampai dengan 27 SKS.

Matakuliah kekhususan berdasarkan jenis kebutuhan khusus di 7 LPTK terfokus pada pendidikan untuk anak dengan gangguan sensori yang mencakup pendidikan untuk gangguan penglihatan dan pendengaran, anak dengan gangguan intelektual, anak dengan gangguan fisik, anak dengan kesulitan belajar, dan anak berbakat (lihat Gambar. 1) ditawarkan sebagai matakuliah wajib dan pilihan.

Tabel 2: Pengukuran tendensi pusat dan SKS untuk calon guru khusus level S1 $(N=7)$

\begin{tabular}{|c|c|c|c|c|c|}
\hline Jumlah SKS & Rerata & $S D$ & Median & Mode & Rentang \\
\hline Matakuliah wajib S-1 & 147.57 & 4.65 & 146 & 142 & $142-155$ \\
\hline Matakuliah Prodi PLB/PK & 100.14 & 14.54 & 102 & 76 & $76-124$ \\
\hline $\begin{array}{l}\text { Matakuliah dengan fokus jenis } \\
\text { kebutuhan khusus (wajib) }\end{array}$ & 18.14 & 5.90 & 20 & 20 & $8-27$ \\
\hline $\begin{array}{l}\text { Matakuliah dengan fokus jenis } \\
\text { kebutuhan khusus (pilihan) }\end{array}$ & 4.71 & 6.40 & 0 & 0 & $0-16$ \\
\hline $\begin{array}{l}\text { Total matakuliah dengan fokus } \\
\text { jenis kekhususan }\end{array}$ & 22.86 & & 22 & 20 & $18-29$ \\
\hline
\end{tabular}

Pendidikan untuk anak berbakat dan pendidikan untuk anak berkesulitan belajar paling banyak ditemukan sebagai matakuliah wajib. Sementara itu, pendidikan untuk anak dengan tuna majemuk ditawarkan sebagai matakuliah wajib di beberapa prodi pendidikan khusus dan gangguan komunikasi sebagai pilihan di satu prodi pendidikan khusus. 


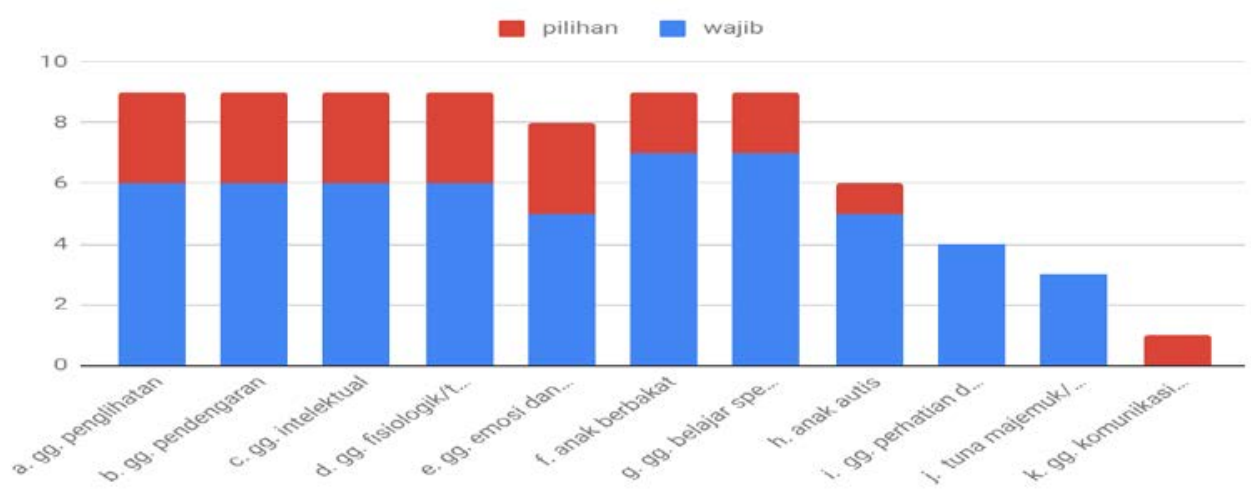

Gambar. 1: Sebaran matakuliah kekhususan berdasarkan jenis kebutuhan khusus

Selain perbedaan sebaran matakuliah kekhusuan, terdapat perbedaan istilah untuk pemberian nama matakuliah di ke-tujuh LPTK dalam penelitian ini. Secara umum, dipergunakan istilah pendidikan untuk anak dengan kekhususan tertentu, satu LPTK masih mempergunakan istilah ketunaan (misal: tunanetra, tunarungu, dsb), dan satu LPTK mempergunakan istilah pendidikan untuk anak dengan hambatan tertentu.

Sasaran Kompetensi Guru dalam Kurikulum S-1 Pendidikan Khusus

Sebaran matakuliah pendukung kompetensi kekhususan bagi guru dilakukan berdasarkan enam kompetensi utama, yaitu: a) identifikasi, asesmen, dan monitoring, b) layanan akademik, c) layanan perilaku, d) layanan transisi, e) layanan kompensatoris, dan f) kemampuan bekerja dalam tim. Kemampuan bekerja dalam tim tidak dijumpai sebagai matakuliah tersendiri dalam kurikulum, namun dimungkinkan terintregasi dalam aktivitas perkuliahan. Hal ini dapat ditelusuri dengan analisis deskripsi matakuliah, observasi perkuliahan, dan interviu mahasiswa maupun dosen pengampu. Matakuliah yang mendukung kelima kompetensi utama dikelompokkan di setiap prodi lalu dibandingkan dengan jumlah matakuliah kekhususan prodi. Hasil akhir dari hitungan sebaran matakuliah kompetensi utama guru khusus untuk ke-tujuh prodi dapat dilihat dalam Gambar 2. Terdapat dua hal yang perlu dicermati, yaitu: sebagian prodi pendidikan khusus mempunyai sebaran matakuliah pendukung kompetensi utama dibawah 50\% dari jumlah matakuliah wajib yang ditetapkan prodi dan kompetensi untuk memberikan layanan perilaku serta layanan transisi tidak dijumpai merata di ke-tujuh prodi pendidikan khusus.

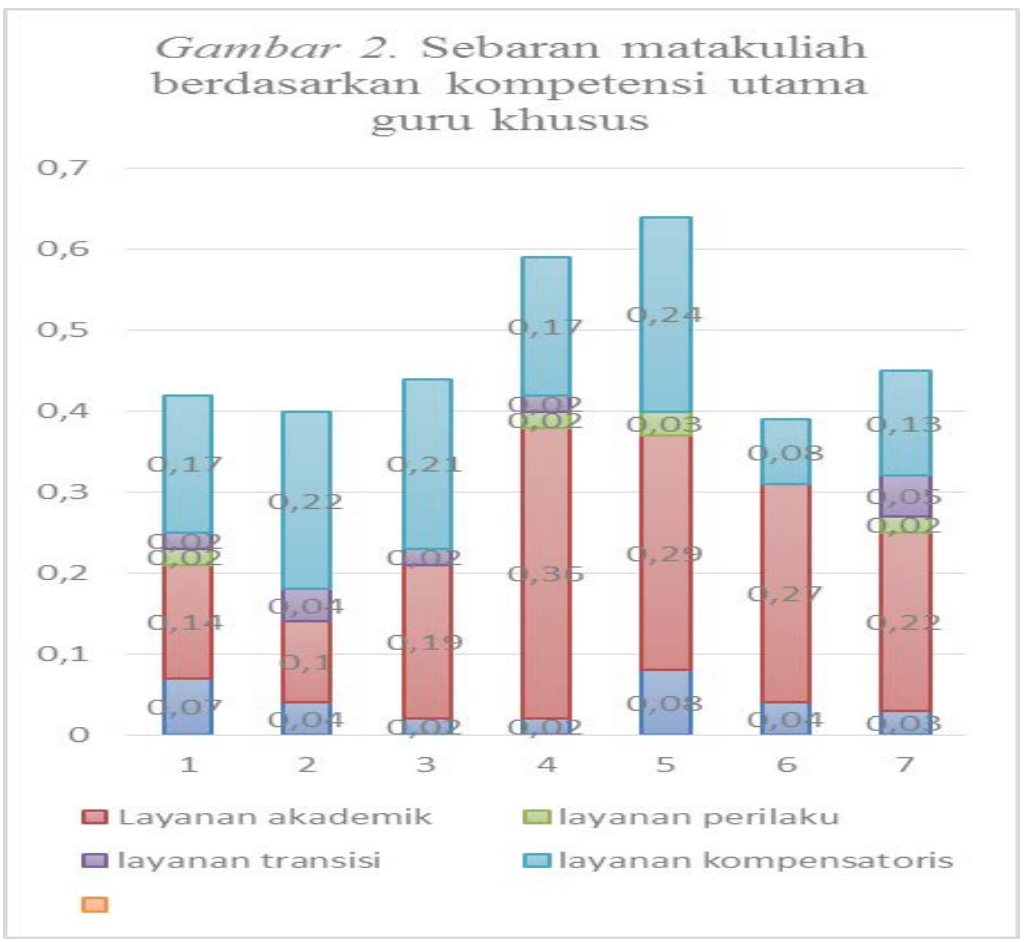

Gambar 2. Sebaran matakuliah berdasarkan kompetensi utama guru khusus 


\section{JPK (J urnal Pendidikan Khusus), 15 (1), 2019 - 29}

Pujaningsih

Prosentase sebaran matakuliah pendukung kompetensi utama prodi pendidikan khusus dapat dikatakan sangat minim bila melihat perbandingan dengan matakuliah wajib prodi dengan kisaran 40\% sampai dengan 60\%. Apabila ditinjau untuk setiap kompetensi utama, maka matakuliah pendukung kompetensi untuk melakukan identifikasi, asesmen, dan monitoring berkisar 2 sampai 7 sks. Sangat dimungkinkan bahwa ketrampilan asesmen juga terintregasi dalam setiap matakuliah pendukung layanan perilaku, akademik, maupun transisi. Secara ideal, penanganan anak berkebutuhan khusus melibatkan berbagai ahli. Namun, keterbatasan akses psikolog maupun dokter untuk melakukan pengukuran fisiologis maupun psikologis banyak ditemukan. Oleh karena itu, tidak mengherankan bila salah satu universitas mengajarkan pengukuran fisiologis maupun psikologis untuk calon guru khusus.

Ditemukan ketimpangan untuk matakuliah pendukung intervensi akademik, perilaku, maupun transisi. Matakuliah pendukung untuk kompetensi guru dalam melakukan intervensi akademik (rerata $=22 \%$ ) paling banyak mendominasi dibandingkan dengan layanan perilaku (rerata $=1 \%$ ) maupun layanan transisi (rerata $=2 \%$ ) untuk semua prodi dalam penelitian ini. Layanan kompensatoris sebagai matakuliah wajib maupun pilihan berdasarkan jenis kekhususan juga mempunyai prosentase tinggi (rerata 17\%) dengan rentang mulai dari 8 SKS sampai dengan 26 SKS. Matakuliah pendukung intervensi perilaku dan layanan transisi tidak ditemui di beberapa prodi dan hal ini perlu mendapat perhatian khusus mengingat kedua layanan tersebut diperlukan calon guru khusus. Matakuliah pendukung layanan transisi beragam dilihat dari jumlah SKS (mulai dari 0 sampai dengan 5 SKS) sementara matakuliah pendukung intervensi perilaku cenderung hampir sama (mulai dari 0 sampai 2 SKS). Keragaman fokus di masing-masing prodi untuk mendukung layanan transisi antaralain: pendidikan vokasional menjadi pilihan untuk semua specialisasi, memberikan matakuliah pendidikan keluarga yang dimungkinkan mempersiapkan transisi anak dengan kebutuhan khusus di masyarakat, pengemasan layanan transisi dalam matakuliah bimbingan konseling.

Pengajaran kompensatoris dikemas beragam oleh prodi pendidikan khusus. Fokus pada kebutuhan anak berkebutuhan khusus dijumpai ketika tawaran perkuliahan difokuskan pada: pengembangan interaksi dan komunikasi, Braille, Orientasi mobilitas, komunikasi alternative dan augmentative. Sementara itu, pengemasan berdasarkan kebutuhan khusus seperti pengajaran kompensatoris untuk anak tunanetra dan berbagai jenis kekhususan lainnya juga banyak ditemukan.

\section{Pembahasan}

Analisis fokus kurikulum calon pendidikan guru khusus menjumpai bahwa sebagian besar prodi pendidikan khusus menggunakan jenis kekhususan anak sebagai fokus penyiapan calon guru khusus. Hal ini perlu dipertimbangkan kembali mengingat kerentanan mislabeling dan kemunkinan ketidaksesuaian kompetensi pendidikan guru pendidikan khusus dengan kebutuhan kompetensi guru pendidikan khusus saat ini.

Hampir semua prodi dalam penelitian ini terfokus pada jenis kebutuhan khusus anak dalam bentuk matakuliah wajib maupun pilihan. Fokus penyiapan calon guru khusus yang terfokus kepada jenis kekhususan anak berkebutuhan khusus tidak menunjang kebutuhan di lapangan. Saat ini, setiap sekolah khusus diwajibkan menerima berbagai kekhususan dan tidak terbatas pada satu kekhususan. Penerapan pendidikan inklusi yang terus didorong oleh pemerintah juga memerlukan kompentensi guru khusus yang tidak spesifik berdasarkan jenis kekhususan anak berkebutuhan khusus. Oleh karena itu pendidikan calon guru khusus berdasarkan kebutuhan anak (Sabornie et al., 2006) dan pemenuhan kebutuhan anak perlu perlu menjadi bahan pertimbangan. Pemberian label yang keliru rentan terjadi karena proses penegakan diagnosis yang kurang didukung ahli juga tidak akan menjadi kendala bila guru dipersiapkan bukan berdasarkan kekhususan anak (Schnoes, Reid, Wagner, \& Marder, 2006; Xin Wei, Yu, \& Shaver, 2014). Hal yang paling mendasar yang menjadi alasan pergeseran fokus penyiapan guru adalah kebermaknaan layanan untuk anak berkebutuhan khusus berdasarkan pemenuhan kebutuhan belajar mereka (Hallahan \& Kauffman, 1977). Oleh karena itu perlu dicermati kembali bagaimana pemenuhan pendidikan untuk anak berkebutuhan khusus diberikan guna mengidentifikasi kompetensi guru pendidikan khusus yang diperlukan.

Saat ini secara umum anak berkebutuhan khusus dilayani di sekolah luar biasa dan sekolah umum. Rentangan kebutuhan khusus mereka mulai dari berat, sedang dan ringan. Penyiapan calon guru berdasar pemenuhan kebutuhan anak disarankan oleh Hallahan dan Kauffman (1977) dan Haring (2016) yang mencakup mencakup: a) anak dengan kekhususan ringan dan b) anak dengan kekhususan berat dapat dipertimbangkan. Penyiapan calon guru berdasarkan dua fokus ini lebih fleksibel karena 


\section{JPK (J urnal Pendidikan Khusus), 15 (1), 2019 - 30}

Pujaningsih

dapat mengantisipasi mislabeling yang rentan terjadi di Indonesia dan mengakomodir pemenuhan kebutuhan khusus anak berdasar cakupan pemenuhan kebutuhan anak. Anak dengan kekhususan ringan mencakup anak dengan gangguan intelektual ringan, anak dengan kesulitan belajar, anak dengan gangguan emosi dan/atau perilaku, anak dengan AD/HD, anak dengan gangguan bahasa, anak dengan autis ringan, anak dengan gangguan kesehatan (Gage, Lierheimer, \& Goran, 2012; Sabornie, Evans, \& Cullinan, 2006). Di negara maju, anak dengan kekhususan ringan banyak dijumpai di sekolah regular dan memerlukan penyesuaian kurikulum. Kondisi ini juga ditemukan di Indonesia (Rudiyati, Pujaningsih, \& Ambarwati, 2010). Dalam penelitian Sari Rudiyati dan rekan (2010) ditemukan bahwa anak dengan kesulitan belajar di sekolah regular ditengarai oleh guru kelas sebagai anak dengan prestasi akademik di bawah rerata kelas, mempunyai masalah perilaku dan dinyatakan guru tidak dapat mengikuti kurikulum seperti teman sebaya. Masalah akademik yang terjadi pada anak dengan kekhususan ringan juga berdampak pada motivasi diri yang rendah hambatan dalam interaksi sosial (Kokkinos \& Antoniadou, 2013; Luciano \& Savage, 2007) karena lingkungan yang belum menerima keunikan mereka. Oleh karena itu, kompetensi guru untuk mampu mendukung anak dengan kekhususan ringan terdiri dari: intervensi akademik, intervensi perilaku, identifikasi, asesmen dan monitor kemajuan, etika profesi, dan memfasilitasi proses transisi dari SD ke SMP dan kemudian ke SMU (Dingle, Falvey, Givner, \& Haager, 2004; Gilberts \& Lignugaris-Kraft, 1997; Zhang, Wang, Stegall, Losinki, \& Katsiyannis, 2018).

Anak dengan kekhususan berat dan sedang banyak dibahas dalam satu kategori kebutuhan khusus (McDonnell, Hardman, \& McDonnell, 2003) karena kebutuhan belajar mereka yang hampir sama. Anak dengan kekhususan berat didefinisikan sebagai "individual yang memerlukan dukungan secara terus menerus dalam satu bidang atau lebih untuk berpartisipasi di masyarakat dan menikmati kualitas hidup seperti anak-anak pada umumnya. Di Indonesia, anak dengan kekhususan sedang dan berat banyak dijumpai di sekolah khusus. Penyiapan guru dengan fokus pemenuhan kebutuhan khusus diharapkan menjawab kebutuhan kompetensi guru pendidikan khusus.

Namun demikian, perundang-undangan di Indonesia belum sepenuhnya mendukung penyediaan guru pendidikan khusus di sekolah inklusi meskipun kebutuhan di lapangan cukup mendesak. Dinamika penyiapan calon guru pendidikan khusus juga banyak dipengaruhi kebijakan pendidikan nasional mengenai layanan untuk anak berkebutuhan khusus di sekolah regular.

Telaah sasaran kompetensi calon guru pendidikan khusus di tujuh prodi menunjukkan keragaman dari sisi porsi (muatan matakuliah prodi dibanding matakuliah wajib fakultas, muatan matakuliah utama dibanding mata kuliah pendukung) dan fokus matakuliah pendukung kompensi guru khusus.

Prosentase matakuliah wajib prodi dibatasi oleh matakuliah wajib yang ditetapkan oleh fakultas dan universitas dengan kisaran (20\% sampai dengan 40\%). Hal ini menjadi tantangan setiap prodi pendidikan khusus untuk melakukan advokasi sejauh mana matakuliah wajib fakultas mendukung kompetensi utama calon guru pendidikan khusus. Dengan 40\%-50\% porsi matakuliah wajib fakultas, dikhawatirkan porsi matakuliah utama untuk calon guru pendidikan khusus menjadi sangat terbatas, misal minimnya fokus perkuliahan untuk intervensi penanganan masalah perilaku yang dijumpai di beberapa prodi.

Penelitian terdahulu sudah banyak menemukan hubungan antara permasalahan akademik dan perilaku (Cho et al., 2015; Mcdermott, Goldberg, Watkins, Stanley, \& Glutting, 2006; Morgan, Farkas, Tufis, \& Sperling, 2008; Zentall \& Beike, 2012). Oleh karena itu layanan kepada anak dengan kebutuhan khusus perlu difokuskan ke akademik maupun perilaku (Riggs, Greenberg, Kusché, \& Pentz, 2006). Ini perlu menjadi catatan bagi prodi pendidikan khusus yang belum menyertakan matakuliah pendukung intervensi perilaku dalam kurikulum saat ini (tiga dari tujuh prodi pendidikan khusus dalam penelitian ini belum menyertakan matakuliah dengan fokus penanganan perilaku).

Minimnya matakuliah pendukung kompetensi utama sangat dimungkinkan karena tingginya jumlah matakuliah pendukung, misal matakuliah medis (misal: psikiatri, audiologi, neurologi, optalmologi, pediatri, anatomi dan psikologi) dan matakuliah psikologis (psikodiagnostik dan pengukuran psikodiagnostik) yang juga diberikan untuk calon guru khusus. Apabila penyiapan guru khusus ditujukan pada fokus kompetensi mereka, maka pemberian matakuliah pendukung medis dan psikologis ini perlu lebih spesifik mengarah pada kebutuhan kompetensi guru pendidikan khusus di lapangan. Sebagai contoh, meskipun kewenangan guru khusus secara etika profesi tidak untuk melakukan pengukuran fisiologis dan psikologis, namun pemahaman tentang hasil pengukuran 
tersebut bagi anak berkebutuhan khusus diperlukan. Cakupan kebutuhan kompetensi guru khusus untuk melakukan identifikasi, asesmen, maupun monitoring masih memerlukan eksplorasi lebih lanjut terutama dengan situasi dan kondisi di Indonesia yang berbeda-beda untuk akses dukungan tenaga professional medis maupun psikologis. Meskipun matakuliah medis maupun psikologis tersebut juga mendukung kolaborasi dengan dokter maupun psikolog (Holland \& Hornby, 1992), namun perlu dikaji kembali fokus perkuliahan medis dan psikologis yang secara langsung mendukung kompetensi utama guru khusus. Oleh karena itu, muatan matakuliah medis dan psikologis sebagai penunjang kompetensi guru khusus perlu mempertimbangkan konsep dan praktik kolaborasi guru pendidikan khusus dengan berbagai ahli medis dan psikologis di Indonesia (Sulaiman, 2018).

Meskipun penelitian ini memberikan kontribusi mendasarkan bagi arah pendidikan calon guru khusus bagi prodi pendidikan khusus yang sudah ada maupun yang sedang merintis pendiriannya, terdapat beberapa keterbatasan. Penelitian ini mempunyai keterbatasan dari sisi sumber data dan analisis data. Sumber data hanya mengacu pada kurikulum yang dipublikasi melalui web universitas sehingga tidak menjangkau materi perkuliahan yang dimungkinkan mengintegrasikan lintas kebutuhan khusus. Selain itu, akurasi dari analisis data tidak menyertakan inter-rater reliability. Oleh karena itu, penelitian berikutnya dapat meningkatkan akurasi analisis data dengan meminimalisir kedua hal tersebut. Penelaahan nama matakuliah tanpa deskripsi matakuliah yang menjelaskan target capaian perkuliahan dapat menimbulkan bias dalam pengelompokan. Misal: matakuliah kewirausahaan dapat ditujukan untuk membangun ketrampilan kewirausahaan calon guru khusus namun juga dapat diarahkan untuk mengembangkan kewirausahaan anak dengan kebutuhan khusus.

Penelusuran lebih mendalam mengenai hal-hal esensial dalam pendidikan calon guru khusus dapat dilakukan melalui penelusuran 'model' pendidikan guru khusus (Brownell, Ross, Colón, \& McCallum, 2005) dengan menggunakan framework pendidikan guru yang effective (DarlingHammond et al., 2000). Dari temuan ini dapat ditemukan aspek-aspek yang mencerminkan pendidikan guru khusus yang berkualitas sehingga peningkatan perguruan tinggi penyelenggara pendidikan khusus dapat terus dibangun secara bersinergi dan berkesinambungan untuk mendukung KKNI. Penelitian empirik untuk mengeksplorasi kompetensi guru khusus dari sudut pandang guru juga diperlukan sehingga ditemukan profil kompentensi guru khusus di konteks Indonesia dan dapat menjadi rujukan profil lulusan S1 pendidikan khusus yang tertuang dalam KKNI.

\section{SIMPULAN}

Perkembangan layanan untuk anak berkebutuhan khusus di Indonesia terus berkembang seiring perbaikan dukungan kebijakan pemerintah. Penyiapan calon guru khusus berdasarkan jenis kebutuhan khusus perlu diperbarui karena tidak sesuai dengan kebutuhan di lapangan dan perubahan layanan anak dengan kebutuhan khusus. Dukungan penelitian-penelitian empirik yang terfokus pada kebutuhan kompetensi guru khusus diperlukan untuk menunjang perubahan kurikulum pendidikan khusus yang diperbarui secara berkala.

\section{DAFTAR PUSTAKA}

Brownell, M. T., Ross, D. D., Colón, E. P., \& McCallum, C. L. (2005). Critical features of special education teacher preparation. The Journal of Special Education, 38(4), 242-252. https://doi.org/10.1177/00224669050380040601

Cho, E., Roberts, G. J., Capin, P., Roberts, G., Miciak, J., \& Vaughn, S. (2015). Cognitive attributes, attention, and self-efficacy of adequate and inadequate responders in a fourth grade reading intervention. Learning Disabilities Research \& Practice, 30(4), 159-170. https://doi.org/10.1111/ldrp.12088

Darling-Hammond, L., Macdonald, M. B., Snyder, J., Whitford, B. L., Ruscoe, G., \& Fickel, L. (2000). Studies of excellence in teacher education: Preparation at the graduate level. Washington, DC: AACTE Publications.

Dingle, M., Falvey, M. A., Givner, C. C., \& Haager, D. (2004). Essential special and general education teacher competencies for preparing teachers for inclusive settings. Issues in Teacher Education, 13(1), 35-50. Retrieved from http://eric.ed.gov/?id=EJ796426

Gage, N. A., Lierheimer, K. S., \& Goran, L. G. (2012). Characteristics of students with high-incidence disabilities broadly defined. Journal of Disability Policy Studies, 23(3), 168-178. https://doi.org/10.1177/1044207311425385 
Gilberts, G. H., \& Lignugaris-Kraft, B. (1997). Classroom management and instruction competencies for preparing elementary and special education teachers. Teaching and Teacher Education, 13(6), 597-610. https://doi.org/10.1016/S0742-051X(97)80003-0

Hadis, F. A. (2005). Toward Inclusive, inclusive education in Indonesia: A country report. Retrieved from http://www.jldd.jp/gtid/global_trend/6-Toward_InclusiveInclusive_Educa-IndonesiaCo.pdf

Hallahan, D. P., \& Kauffman, J. M. (1977). Labels, categories, behaviors: ED, LD, and EMR reconsidered. The Journal of Special Education, 11(2), 139-149. https://doi.org/10.1177/002246697701100202

Haring, N. G. (2016). Republication of "educational services for the severely and profoundly handicapped. The Journal of Special Education, 50(2), 69-74. https://doi.org/10.1177/0022466916651465

Holland, J. M., \& Hornby, \& G. (1992). Competences for teachers of children with special educational needs. Journal of In-Service Education, 18(1), 59-62. https://doi.org/10.1080/0305763920180109

Kokkinos, C. M., \& Antoniadou, N. (2013). Bullying and victimization experiences in elementary school students nominated by their teachers for Specific Learning Disabilities. School Psychology International, 34(6), 674-690. https://doi.org/10.1177/0143034313479712

Kurniawati, F., Minnaert, A., Mangunsong, F., \& Ahmed, W. (2012). Empirical study on primary school teachers' attitudes towards inclusive education in Jakarta, Indonesia. Procedia - Social and Behavioral Sciences, 69, 1430-1436. https://doi.org/10.1016/j.sbspro.2012.12.082

Luciano, S., \& Savage, R. S. (2007). Bullying risk in children with learning difficulties in inclusive educational settings. Canadian Journal of School Psychology, 22(1), 14-31. https://doi.org/10.1177/0829573507301039

Mcdermott, P. A., Goldberg, M. M., Watkins, M. W., Stanley, J. L., \& Glutting, J. J. (2006). A nationwide epidemiologic modeling study of LD: Risk, protection, and unintended impact. Journal of Learning Disabilities, 39(3), 230-251.

McDonnell, J. J., Hardman, M. L., \& McDonnell, A. P. (2003). Introduction to persons with moderate and severe disabilities: Educational and social issues (2nd Ed.). Boston : Allyn and Bacon .

Morgan, P. L., Farkas, G., Tufis, P. A., \& Sperling, R. A. (2008). Are reading and behavior problems risk factors for each other? Journal of Learning Disabilities, 41(5), 417-436. https://doi.org/10.1177/0022219408321123

Poernomo, B. (2016). The implementation of inclusive education in Indonesia : Current problems and challenges. American International Journal of Social Science, 5(3), 144-150. Retrieved from http://www.umm.ac.id/en/detail-4-benang-kusut-pendidikan-indonesia-opini-umm.html.

Rahardja, D. (2016). Pendidikan luar biasa dalam perspektif dewasa ini. JASSI ANAKKU, 9(1), 76-88. Retrieved from http://ejournal.upi.edu/index.php/jassi/article/view/3911/2792

Riggs, N. R., Greenberg, M. T., Kusché, C. A., \& Pentz, M. A. (2006). The mediational role of neurocognition in the behavioral outcomes of a social-emotional prevention program in elementary school students: Effects of the PATHS curriculum. Prevention Science, 7(1), 91102. https://doi.org/10.1007/s11121-005-0022-1

Rudiyati, S. (2012). Substansi komponen kompetensi guru sekolah inklusif bagi anak berkelainan/berkebutuhan khusus pendidikan khusus. Jurnal Penelitian Dan Evaluasi Pendidikan, 16(2), 533-552. Retrieved from https://journal.uny.ac.id/index.php/jpep/article/view/1130/2820

Rudiyati, S., Pujaningsih, \& Ambarwati, U. (2010). Penanganan anak berkesulitan belajar berbasis akomodasi pembelajaran. Jurnal Kependidikan, 40(2), 187-200. Retrieved from https://journal.uny.ac.id/index.php/jk/article/view/498/355

Rudiyati, S., Pujaningsih, P., \& Mumpuniarti, M. (2017). Teacher knowledge and experience dealing with students with learning disabilities in inclusive elementary school and implications to learning accommodation and modification. Proceedings of the 1st Yogyakarta International Conference on Educational Management/Administration and Pedagogy (YICEMAP 2017). https://doi.org/10.2991/yicemap-17.2017.47 
Sabornie, E. J., Evans, C., \& Cullinan, D. (2006). Comparing characteristics of high-incidence disability groups. Remedial and Special Education, 27(2), 95-104. https://doi.org/10.1177/07419325060270020701

Schnoes, C., Reid, R., Wagner, M., \& Marder, C. (2006). ADHD among students receiving special education services: A national survey. Exeptional Children, 72(4), 483-496.

Sindelar, P. T., Brownell, M. T., \& Billingsley, B. (2010). Special Education Teacher Education Research: Current Status and Future Directions. Teacher Education and Special Education: The Journal of the Teacher Education Division of the Council for Exceptional Children, 33(1), 824. https://doi.org/10.1177/0888406409358593

Sulaiman, ahmad. (2018). Promoting collaborative consultation to improve the quality of inclusive education in Indonesia. Academic Journal Perspective: Language, Education, and Literature, 6(2), 80-88. Retrieved from http://jurnal.unswagati.ac.id/index.php/Perspective/article/view/1357

Sunardi, Yusuf, M., Gunarhadi, Priyono, Yeager, J. L., \& Yeager, J. L. (2011). The implementation of inclusive education for students with special needs in Indonesia. Excellence in Higher Education, 2(1), 1-10. https://doi.org/10.5195/EHE.2011.27

Tarnoto, N. (2016). Permasalahan-permasalahan yang dihadapi sekolah penyelenggara pendidikan inklusi pada tingkat SD. Humanitas, 13(1), 50-61. Retrieved from http://digilib.mercubuana.ac.id/manager/t!@file_artikel_abstrak/Isi_Artikel_626984286959.pdf

Xin Wei, Yu, J., \& Shaver, D. (2014). Longitudinal effects of ADHD in children with learning disabilities or emotional disturbances. Exceptional Children, 80(2), 205-219. Retrieved from https://login.proxy.lib.uni.edu/login?url=http://search.ebscohost.com/login.aspx?direct=true\&db $=$ eft \&AN=93301928\&site=ehost-live

Yusuf, M. (2012). Kinerja kepala sekolah dan guru dalam mengimplementasikan pendidikan inklusif. Jurnal Pendidikan Dan Kebudayaan, 18(4), 382-393. Retrieved from http://jurnaldikbud.kemdikbud.go.id/index.php/jpnk/article/view/96/93

Zentall, S. S., \& Beike, S. M. (2012). Achievement and social goals of younger and older elementary students: Response to academic and social failure. Learning Disability Quarterly, 35(1), 39-53. https://doi.org/10.1177/0731948711429009

Zhang, D., Wang, Q., Stegall, J., Losinki, M., \& Katsiyannis, A. (2018). The construction and initial validation of the student teachers' efficacy scale for teaching students with disabilities. Remedial and Special Education, 39(1), 39-52. https://doi.org/10.1177/0741932516686059 